\title{
Background, Experiences, and the Future of Our Profession
}

\section{Richard L. Kilmer}

It is indeed an honor to receive the Southern Agricultural Economics Association Lifetime Achievement Award. I would be remiss if I did not recognize my wife, Linda, with whom I am sharing this award, as she has been with me for the past 39 years. We met in the Agricultural Economics Department at Purdue University where she worked and where I started my professional career as a student in agricultural economics. She has been with me every step of the way. I am very proud of her and of our three lovely children and five grandchildren.

I grew up on a dairy/corn/soybean farm in north central Indiana, where my brother has a hog operation and my parents are in retirement. Family has always been important in my life. Linda and I still return to the home farm every summer to see family and to return to our roots. I was part of the exodus from the farm to the city when technology made it possible for fewer people to feed the increasing number of people who were pursuing careers off the farm. At that time, I unknowingly participated in change that would see the number of farms drop from 4 million in 1960 (U.S. Department of Agriculture, 2007b) to approximately 2 million in 2007 (U.S. Department of Agriculture, 2007a). The farm population has dropped by approximately the same amount. I have no regrets about leaving the farm, where I learned the values and work

Richard L. Kilmer is a professor in the Food and Resource Economics Department at the University of Florida, Gainesville, Florida. ethic that have served me well in life. The roots run deep, and I have been able to participate and interact in the farm community as an agricultural economist.

\section{Farm to University}

In my college days, most students entered the School of Agriculture at Purdue University without choosing a department. The first year contained a basic set of courses that everyone took and, during that year, we were encouraged to choose our department. We all took a 1-hour credit course, where each of the departments in the School of Agriculture were given one class period to introduce their department and share with us why we should be interested in majoring in that department. Dr. F.N. Andrews represented agricultural economics, and he emphasized that all the majors needed the economics and business background provided in his department. Coming from a farm where family members provided the labor for the farming operation, I felt that I had a good background in production agriculture and that what I needed was the economics and business side of the equation. So the words of Dr. Andrew resonated very clearly with me.

Although I took undergraduate economics and business courses, the marketing system was an intriguing structure about which I wanted to know more. On the farm, we kept a 1-year feed supply for the cows. The corn and soybeans beyond that need always went to the local elevator, which stored the corn on the 
ground with no protection from the weather and paid rock-bottom prices. That bothered me because I saw trucks of corn bypassing the local elevator for a large terminal market that was paying higher prices than my Dad was receiving. Then there was this thing called the futures market in Chicago that helped you receive a guaranteed price. Dad would listen to the radio on a daily basis to see what the corn and soybean prices were doing. This information was important to him, and it made me realize that prices were higher later in the marketing year. With this background, I spent my professional life performing research on the agricultural marketing system. I have participated, along with other researchers, in the improvement in efficiency of the movement of commodities from the farm to the consumer.

\section{Agricultural Marketing}

I did my dissertation on merger restrictions and market-share restrictions on the fluid milk-processing industry in Ohio (Kilmer and Hahn). In the 1960s and 1970s, there was much concern about the increasing concentration in agriculture and the entire economy. The Federal Trade Commission was active in an attempt to slow the concentration by controlling mergers. The number of buyers and sellers was important to maintain a competitive economy during that era. However, technology took over, and the increasing size of operations with significant economies to size caused the number of firms to decrease. The prices charged in a market with a large number of buyers and sellers would have been higher than a noncompetitive price charged by large firms who were able to charge lower prices than small producers because of significantly lower costs due to economies of size. So nowadays, the number of firms in an industry is not the overriding factor that is evaluated when determining the impact on an industry of a decrease in the number of firms.

Another change that has occurred over the course of my professional life is the significant change in the vertical market system. The vertical market system determines what con- sumers want, when they want it, where they want it, and what price they are willing to pay for the product. The more levels there are in the vertical system, the more difficult the communication process. Product arrives at the consumer level in quantities that exceeds or is less than demand; that is, supply never equals demand. Generally, there is excess demand or excess supply. Excess demand means that the prices increase to equate supply and demand, and excess supply results in a fall in prices. Supply ends up equaling demand; however, price changes were significant. So, one could say that demand equaled supply after significant price adjustments.

A sign of improvement in the supply and demand balance is the increase in the number of exchanges that occur without a spot market. Over time, the percentage of agricultural production under production and marketing contracts has increased from $11 \%$ in 1969 to 39\% in 2003 (MacDonald and Korb). Large farms with over $\$ 1,000,000$ in sales had $53 \%$ of their production covered by contracts in 2003, followed by livestock at $47 \%$ and crops at $39 \%$. These figures do not include production that is vertically integrated. The lowest crop contracts were wheat at $7.6 \%$, soybeans at $14.0 \%$, and corn at $14.3 \%$. For livestock, cattle contracts were the lowest at $28.9 \%$, and poultry and egg contracts were the highest at $88.2 \%$. It was also found that the average contract prices were greater than or equal to the average spot market prices. So, vertical coordination has improved in the agricultural marketing system.

The Federal Reserve Bank of Dallas recently did a study on the vertical market systems of the United States. They found that logistics costs, which include transportation costs and inventory carrying costs, declined from $16 \%$ of GDP in 1981 to $8.5 \%$ in 2005. At the same time, the inventory-to-sales ratio also declined, which says that the inventory volume required to service sales has decreased. Furthermore, they found that recessions are less frequent and less volatile, and improvement in vertical coordination is the main reason, primarily due to a reduction in the level and variability of inventories, which normally 
cause a recession because firms stop ordering new supplies. In agriculture, we do not have the same supply control as other industries; however, I am certain that logistics costs in the agricultural marketing system have improved significantly as the percent of agricultural production under production and marketing contracts has increased over time.

\section{The Future of Our Profession}

Agricultural Economics is an applied profession. We take economic and business concepts and apply them to real-world problems. The problem set has generally been within the School of Agriculture. This problem-set includes production, farms, agribusiness, agricultural marketing, land, water, natural resources, rural communities, community development, international trade, and economic development. Over time, the emphasis placed on different parts of the problem-set has changed. The most obvious change has been the shift in emphasis from the farm and production agriculture to virtually every other part of the problem-set.

This change in emphasis brought about a name change in 1968 from the American Farm Economic Association to the American Agricultural Economics Association. At the 2007 AAEA annual meetings in Portland, OR, another name change will be voted on by the membership. Our profession has been dynamic because the emphasis on members of the problem set has changed. One can say that our profession has evolved, as the name change suggests, or that the American Farm Economic Association profession died in 1967, and the American Agricultural Economics Association profession was born in 1968. It seems that the American Agricultural Economics Association profession may die, and a new profession may be born at the AAEA 2007 annual meeting. What has remained constant, however, is that we are an applied profession that uses economic and business concepts on a problem-set, within which, the emphasis among the parts of the problem-set has changed over time. I am pleased to be a part of a profession that is dynamic and that changes with the times.

\section{References}

Federal Reserve Bank of Dallas. Supply Chain Management: The Science of Better, Faster, Cheaper-In Depth, January 2005-Dallas Fed. Internet site: http://dallasfed.org/research/ indepth/2005/id0501.pdf (Accessed February 26, 2007).

Kilmer, R.L., and D. Hahn. "Effects of Market Share and Anti-Merger Policies on the Fluid Milk Processing Industry." American Journal of Agricultural Economics 60(August 1978):385-92.

MacDonald, J.M., and P. Korb. "Agricultural Contracting Update: Contracts in 2003." Economic Information Bulletin No. 9. Washington, DC: U.S. Department of Agriculture-Economic Research Service, January 2006.

U.S. Department of Agriculture-Economic Research Service. Farm Structure: Questions and Answers. Internet site: http://www.ers.usda.gov/ Briefing/FarmStructure/data/tablel.htm (Accessed February 26, 2007a).

- Farm Structure: Questions and Answers. Internet site: http://www.ers.usda.gov/Briefing/ FarmStructure/gallery/landinfarms.htm (Accessed February 26, 2007b). 